Journal of Social Sciences 4 (1): 62-67, 2008

ISSN 1549-3652

(C) 2008 Science Publications

\title{
How Prepared are Trainee Teachers of University Putra Malaysia (UPM) to Integrate Computer Technology in Classroom Teaching?
}

\author{
${ }^{1}$ Shamsiah Mohamed and ${ }^{2} \mathrm{Ab}$. Rahim Bakar \\ ${ }^{1}$ Department of Mathematics, University Putra Malaysia, Malaysia \\ ${ }^{2}$ Faculty of Educational Studies, University Putra Malaysia, 43400 Serdang, Selangor, Malaysia
}

\begin{abstract}
This research is a presentation of a study on trainee teachers' preparedness to integrate computer technology in teaching. One-hundred and thirty-nine trainee teachers participated in the study. They comprised $12.2 \%$ male students and $87.8 \%$ female. They majored in agricultural science, home-science, language, economics or accounting and science and mathematics. Their academic achievements were between 2.00 and 3.74 (Mean $=2.91, \mathrm{SD}=0.41)$. More than $50 \%$ of them felt ready to integrate computer in teaching. In general, UPM trainee teachers had positive attitudes towards the integration of computer in teaching. They had a moderately high computer efficacy. There are significant relationships between attitudes towards the integration of computers in teaching and their perceptions about their abilities to work on: data base graphics, electronic spreadsheet and word processing.
\end{abstract}

Key words: Student teachers; computer integration in teaching; computer attitudes; computer efficacy

\section{INTRODUCTION}

Malaysia places a great emphasis on information technology by making it a dominant feature of the national policy. In fact the Prime Minister of Malaysia foresees Malaysia to be a pioneer in electronic governance, a multi-mediated paperless administration. To be able to achieve these objectives, Malaysia has to prepare its workforce to be competent in the related technology and it has to begin in schools. Computer technology was introduced in Malaysian school system as early as 1983. The objective at that time was to equip students with basic knowledge of computers and its applications. It was not until late 1990's that a more rigorous effort to integrate computers in Malaysian educational system was made. A large amount of budget has been proposed by the government to initiate the infrastructure development and training needed to prepare students for the information age. In the 2002 budget, the government has proposed a sum of more than RM200 million for the computerization of schools.

Computer technology has become an important integral tool in teaching field. The use of computer technology is said to benefit both students and teachers. Its usage alters the traditional roles of teachers in the classroom. In the past, teachers present knowledge and information to students. Nowadays, students are required to search for the knowledge and information with the helps and guidance from teachers. To be able to function in a technology savvy environment, teachers should be well trained to make use of the required technology. Newly-trained teachers as well as teachers who are already in-service should possess skills and knowledge needed to function effectively in school environment rich with technology. The demand for teachers who are well versed in technology has caused teacher-training institutions to make changes in teacher education curriculum. If the school system requires that all teachers be computer literate and able to integrate computers in their teaching, then a pre-service education needs to have the technology fully integrated in their programs [1]. All teacher education programs conducted by public universities in Malaysia and teacher-training colleges have included at least a course related to computer or information communication technology in the curriculum.

The Government is not the only body that has taken steps to train teachers in Malaysia to be literate in the new technology. Private sectors like Intel Corporation supported by Microsoft Corporation have done their bits too. Intel together with Microsoft Corporation has implemented a global teacher development ICT-in-Education program called Teach to the Future. The program is aimed at training a total of 400,000 classroom teachers in 20 countries worldwide by the year 2003. This particularly gives

Corresponding Author: Ab. Rahim Bakar, Faculty of Educational Studies, Universiti Putra Malaysia, 43400 Serdang, Selangor, Malaysia Tel: 60389468111 Fax: 60389467905 
inputs on how to promote inquiry/project-based learning and effective integration of computer technology and internet into existing curriculum teaching to enhance students' learning and achievements through research, communication and productive strategies and tools. In Malaysia, Intel's goal is to train over 12,000 teachers by the end of 2002 [2]. Teachers in Malaysia are very fortunate in the sense that wherever they are located, they are helped with the acquisition of knowledge and skills in ICT. For this purpose, a Mobile Internet Unit developed by the AsiaPacific Development Information Program in collaboration with MIMOS (Malaysian Institute of Microelectronics Systems) was developed. It intends to expose secondary school teachers and students to new technologies. It also inspires the government to take an electronic classroom to schools in the marginalizedurban areas for demonstrative and instructional purposes [2].

\section{RESEARCH PROBLEM}

Computer technology has become a prominent tool in teaching and learning process. Nowadays, teachers are required to use this technology in lesson delivery. A technology supported education system better known as a SMART SCHOOL was introduced in 1999 with the objectives of preparing school leavers for the Information Age. This was intended to bring about a systemic change in education, from an exam-dominated culture to a culture of thinking and creative knowledge emphasizing science and technology education with a focus on creativity and innovation as also equipping students with IT competencies. The success of using this technology is very much dependent on teachers. Teachers have to have right attitudes about using computers in teaching. They have to be knowledgeable in using the technology. They have to have skills in using the technology. The question is to what extent our students and teachers feel prepared to integrate computer technology in teaching?

\section{OBJECTIVES OF THE STUDY}

Primarily, the objective of the study has been to determine student teachers' preparedness to integrate computer technology in teaching. Specifically, the study was to determine student teachers': (1) attitudes to integration of computer technology in teaching, (2) their efficacy in using selected software, (3) their perceptions about the computing knowledge they have, (4) their perceptions of their confidence to integrate computer in teaching and (5) their interest to integrate computer in teaching.

\section{RESEARCH PROCEDURES}

This is a descriptive survey research. Questionnaires were mailed to two hundred vocational pre-service teachers who underwent a 12 weeks teaching practice in several secondary schools. Preservice teachers were requested to return the completed questionnaires within two weeks after the receipt of the questionnaires. One-hundred and thirty-nine questionnaires were returned to the researcher. The initial check showed that the respondents answered almost all the questions so, none of the questionnaires was discarded. No follow-up was made to those who did not return the questionnaire. However, in order to have the results generalized to at least the sample, a comparison of the of late and early respondents had to be made [3]. Following that, a comparison of late and early respondents on their academic achievement (one of the variables investigated) was made. The result of a t-test was not significant $[\mathrm{t}(132)=1.93$, $\mathrm{p}>0.05]$. Thus, the findings could be generalized to the sample.

How was student teachers' preparedness determined?: Trainee teachers' preparedness was determined based on: (1) attitudes about the integration of computer technology in teaching, (2) their efficacy in using selected software, (3) their perception about the computing knowledge they have, (4) their perceptions about their confidence to integrate computer in teaching and (5) their interest in integrating computers in teaching.

Measurement of computer self-efficacy: One can define computer self-efficacy as one's belief about his or her ability to execute computer related tasks. For the purpose of this research the author constructed a series of questions comprising ones ability to perform tasks related to word processing (44 questions), spreadsheet (29 questions), graphic (23 questions) and developing data bases (14 questions). All questions were measured on a 5-point Likert scale format ranging from very skillful (5) to very unskillful (1). Respondents were asked that to what extent they believed that they could perform the related computer tasks.

Student teachers' attitudes towards the integration of computer in teaching: The research instrument used to solicit the needed information consisted of attitudes items, one question each on gender, major and minor areas of study, academic achievement and interest towards the integration of computers in teaching, level of confidence and knowledge of computers. Students' 
and teachers' attitude towards integration of computers in teaching was assessed using a 5-point Likert Scale ( $5=$ Strongly agree, $4=$ Agree, $3=$ Moderately agree, $2=$ Disagree, $1=$ Strongly disagree). Originally, the measure consisted of 36 items. However, based on the results of pilot test, 5 items were eliminated. The 5 items were eliminated because either the statements had near zero correlations or negative correlations. The final questionnaire consisted of 31 attitude statements. An analysis of the responses from 30 student teachers who did not participate in the study yielded a reliability coefficient of 0.90 for the attitude scale.

\section{RESULTS}

A total of 139 student teachers responded to the survey. They comprised $12.2 \%$ male and $87.8 \%$ female students. About $13.7 \%$ of the respondents majored in agricultural science, $17.3 \%$ majored in home-science, $15.1 \%$ majored in language, $22.3 \%$ majored in either economics or accounting and $8.6 \%$ majored in science and mathematics. Their choices of minors were living skills $(25.5 \%)$, business studies (70.5\%) and economics (4.3\%). Their academic achievement as determined using the Cumulative Grade-point Average (CGPA) ranged between 2.00 and 3.74 (Mean $=2.91$, $\mathrm{SD}=0.41$ ).

Perceptions about their confidence to integrate computer in teaching: Student teachers' perceptions about the level of confidence they had for integrating computer technology were determined by asking a specific question: 'How confident are you to integrate computer in teaching'. A 5-point Likert scale was used to measure the level of knowledge $(5=$ Very confident, $1=$ Least confident). In terms of computer usage the study showed that some respondents have been using computers for more than 10 years while some others have been using them only off late. On an average, students had used computer for about 5.2 years ( $\mathrm{SD}=2.73$ years). The study showed that student and teachers were moderately confident in using computers $($ mean $=3.71$ on a scale of $1-5, \mathrm{SD}=0.55)$.

Perception about the computing knowledge and their interest in the integration of computer in teaching: Student teachers' perceptions about their knowledge in computing were determined by asking a specific question 'How much knowledge do you have about computing'. A 5-point Likert scale was used to measure the level of knowledge $(5=$ in-depth knowledge, 1 = little knowledge). Student teachers' perceptions about their interest to integrate computer technology were determined by asking a specific question 'How interested you are in getting computer integrated in teaching'. A 5-point Likert scale was used to measure the level of interest $(5=$ High interest, $1=$ Little interest). The study showed that students and teachers had a moderate level of knowledge about computers (mean $=3.47$ on a scale of $1-5, \mathrm{SD}=0.57$ ). However, they had quite a high level of interest in using computers $($ mean $=4.12$ on a scale of $1-5, \mathrm{SD}=1.01)$.

Student teachers' attitudes towards using computer in teaching: Student teachers' attitudes towards the integration of computers in teaching were assessed using a questionnaire consisting of 31 attitude statements. The total score obtained by the respondents ranged between 89 and 145 with a mean of 118.4 $(\mathrm{SD}=11.23)$. The total scale mean was 103.8 $(\mathrm{SD}=8.36)$. The median was 104 and the mode was 105. In general, trainee teachers agreed with most of the statements. The items' mean was 3.95 on a scale of 1 to $5(\mathrm{SD}=0.33)$. Fourteen statements $(45.0 \%)$ had scores of 4.0 and above, 12 statements $(38.7 \%)$ had scores between 3.5 and 3.9 and eight statements (16.3\%) had scores between 3.0 and 3.49 (Table 1).

A correlation analysis was conducted to determine if any relationship between student teachers' attitudes towards the integration of computers in teaching and selected independent variables existed. Low significant correlations were found between student teachers attitudes and their level of knowledge about computers $(\mathrm{r}=0.21, \mathrm{p}<0.05)$, level of confidence $(\mathrm{r}=0.20$, $\mathrm{p}<0.05)$ and their intention to integrate computers in teaching $\left(r_{p b}=0.20, p<0.05\right)$. No significant correlations were found between the attitudes towards the integration of computers and whether or not the trainees owned a computer, the number of years they had been using computers and their interests towards computers. A one-way ANOVA test was performed to determine if there was any difference in attitude among students of different majors. It was found that attitude towards the integration of computer in teaching did not differ among trainees of different majors $\left(\mathrm{F}_{(6,138)}=1.902\right.$, $\mathrm{p}>0.05$ ) and among trainees with different minors $\left(F_{(2,134)}=0.174, p>0.05\right)$. The study also showed that attitudes towards the integration of computer technology in teaching did not differ $\left(\mathrm{t}_{(136)}=0.31\right.$, 
Table 1: Means and SD of student teachers' attitudes towards the integration of computer technology in teaching $(\mathrm{n}=139)$

\begin{tabular}{|c|c|c|}
\hline Statement of attitudes towards the integration of computer in teaching & Mean & SD \\
\hline I have a confidence when talking about computers with my friends & 3.38 & 0.82 \\
\hline I am interested to enroll in computer in education courses & 4.51 & 0.77 \\
\hline The use of computer in education does not make nervous & 3.75 & 1.10 \\
\hline Using computer in teaching does not complicate a teacher's job & 3.91 & 1.00 \\
\hline I have the ability to use computer in teaching & 3.87 & 0.73 \\
\hline I am knowledgeable about computerization in education & 3.23 & 0.75 \\
\hline I have the confidence when using computers for teaching & 3.78 & 0.66 \\
\hline I have the skills to use computers in teaching & 3.44 & 0.79 \\
\hline I is not difficult for me to use computer in teaching & 3.72 & 1.00 \\
\hline I am knowledgeable about computer some programs & 3.81 & 0.75 \\
\hline I like to discuss with friends about computer in education & 3.87 & 0.71 \\
\hline I like to use computer in teaching & 4.02 & 0.71 \\
\hline Integrating computer technology in teaching is interesting & 4.22 & 0.71 \\
\hline It is difficult for me to stop once I start using computer & 4.64 & 0.86 \\
\hline If I have problem in using computers, I will seek helps from others & 4.48 & 0.66 \\
\hline Using computers in teaching will increase students' motivation & 4.34 & 0.68 \\
\hline Using computers in teaching improves teaching effectiveness & 4.22 & 0.61 \\
\hline Using computers in teaching will make learning more effective & 4.26 & 0.67 \\
\hline Using computers in teaching will enable teachers to teach a difficult to more easily & 3.87 & 0.77 \\
\hline There is not much a problem in using computers in teaching & 3.58 & 0.92 \\
\hline Using computers in teaching will give time for teachers to help academically poor students & 3.44 & 0.86 \\
\hline Using computer in teaching encourages students' creativity & 4.23 & 0.67 \\
\hline Using computers in teaching gives opportunity for good students to excel in their studies & 4.34 & 0.56 \\
\hline Using computers in teaching makes students enjoy the learning & 3.86 & 0.94 \\
\hline Using computers in teaching increase students' self-confident & 4.03 & 0.64 \\
\hline Using computers in teaching improve students' academic performance & 3.93 & 0.69 \\
\hline Using computers in teaching increases students' knowledge & 4.25 & 0.59 \\
\hline Using computers in teaching enable students to get information faster & 4.24 & 0.64 \\
\hline Using computers in teaching increases students' interests in subject-matter & 4.21 & 0.66 \\
\hline Using computers in teaching makes learning mechanical & 3.81 & 0.79 \\
\hline Using computers in teaching does not bore me & 4.09 & 0.94 \\
\hline
\end{tabular}

Item means $=3.95, \mathrm{SD}=0.33$, Scale mean $=118.4, \mathrm{SD}=11.23$, (Scale: $1=$ Strongly disagree, $2=$ Disagree, $3=$ Moderately disagree, $4=$ Agree, $5=$ Strongly agree)

$\mathrm{p}>0.05)$ among students who had or had not taken a computer course offered by the Faculty of Education, UPM $($ Mean $=118.9, \mathrm{SD}=10.22,118.3, \mathrm{SD}=11.79$, respectively).

Student teachers' computer self-efficacy: An analysis was done to determine student teachers' computer selfefficacy for specific computer task mainly the ability to do word processing, to use electronic spreadsheet, to create data base and graphic. The mean score for word processing abilities was 173.25 with an SD of 23.45. The mean score for abilities to use electronic spreadsheet was 102.75 with an SD of 21.46. The mean scores for the abilities to use graphic was 84.83 with an SD of 20.99. The mean score of the abilities to use data base tools were 39.65 with an SD of 12.44. Their computer self-efficacy was classified as low, moderate and high. About one-half of the total students and teachers surveyed could be classified as having moderate efficacy in using electronic spreadsheet; about one-half the student teachers can be classified as having high efficacy in word processing, about $57 \%$ of the students surveyed can be classified as having moderate efficacy in graphic work and approximately $51 \%$ of the students surveyed were moderately efficacious in creating data base.
Several significant relationships were observed between computer self-efficacy and the selected variables (Table 2 ). There are significant relationships between attitudes towards the integration of computers in teaching and their perceptions about their abilities to work on: data base $(\mathrm{r}=0.298, \mathrm{p}=0.000)$, graphics $(\mathrm{r}=0.402, \mathrm{p}=$ $0.000)$, electronic spreadsheet $(\mathrm{r}=0.437, \mathrm{p}=0.000)$ and word processing $(\mathrm{r}=0.425, \mathrm{p}=0.000)$. Academic performance correlated significantly with data base skills $(r=0.185, p<0.05)$. No significant correlations were observed between academic performance and graphic skills, skills in using electronic spreadsheet and/or word processing. However, h of computer usage did have some influence on computer efficacy. The study showed that hour of computer usage correlated significantly with data base skill, graphic skills, electronic spreadsheet and word processing skills (Table 2).

Computer self-efficacy does not differ by gender (Table 3). A significant difference of computer selfefficacy was observed among studentteachers who had taken or had not taken computer course while at the university and also in terms of students' level of knowledge about computing. 
Table 2: Relationship between computer self-efficacy and the attitudes towards the integration computer in teaching, academic performance and hours of computer usage

\begin{tabular}{llll}
\hline Computer self-efficacy & Attitudes & CGPA & Hours of computer usage \\
\hline Data base skills & $\mathrm{r}=0.298, \mathrm{p}<0.05$ & $\mathrm{r}=0.185, \mathrm{p}<0.05$ & $\mathrm{r}=0.254, \mathrm{p}<0.05$ \\
Graphic skills & $\mathrm{r}=0.402, \mathrm{p}<0.05$ & $\mathrm{r}=0.08, \mathrm{p}>0.05$ & $\mathrm{r}=0.282, \mathrm{p}<0.05$ \\
Electronic spreadsheet skills & $\mathrm{r}=0.420, \mathrm{p}<0.05$ & $\mathrm{r}=0.153, \mathrm{p}>0.05$ & $\mathrm{r}=0.298, \mathrm{p}<0.05$ \\
Word processing skills & $\mathrm{r}=0.425, \mathrm{p}<0.05$ & $\mathrm{r}=0.066, \mathrm{p}>0.05$ & $\mathrm{r}=0.266, \mathrm{p}<0.05$ \\
\hline
\end{tabular}

Table 3: Means and standard deviations of student teachers' believes about their abilities in using four types of software for teaching Selected characteristics

\begin{tabular}{|c|c|c|c|c|c|c|}
\hline \multirow[b]{2}{*}{ Types of software } & \multicolumn{2}{|c|}{ Enrollment in computer classes } & \multicolumn{2}{|l|}{ Gender } & \multicolumn{2}{|c|}{ Levels of knowledge } \\
\hline & Yes & No & Male & Female & Little knowledge & Some knowledge \\
\hline \multicolumn{7}{|l|}{ Dbase } \\
\hline Mean & 43.36 & 37.14 & 42.43 & 39.50 & 35.90 & 43.64 \\
\hline $\mathrm{SD}$ & 11.98 & 12.26 & 14.75 & 11.96 & 12.33 & 11.35 \\
\hline Test & \multicolumn{2}{|c|}{$\mathrm{T}=2.94, \mathrm{p}=0.004$} & \multicolumn{2}{|l|}{$\mathrm{T}=0.89, \mathrm{p}=0.37$} & \multicolumn{2}{|c|}{$\mathrm{T}=-3.83, \mathrm{p}=0.000$} \\
\hline \multicolumn{7}{|l|}{ Graphics } \\
\hline Mean & 95.05 & 77.62 & 88.75 & 84.05 & 77.67 & 92.10 \\
\hline SD. & 16.59 & 20.96 & 25.04 & 20.34 & 21.36 & 18.03 \\
\hline Test & \multicolumn{2}{|c|}{$\mathrm{T}=5.15, \mathrm{p}=0.000$} & \multicolumn{2}{|l|}{$\mathrm{T}=.084, \mathrm{p}=0.40$} & \multicolumn{2}{|c|}{$\mathrm{T}=-4.24, \mathrm{p}=0.000$} \\
\hline \multicolumn{7}{|l|}{ Spreadsheet } \\
\hline Mean & 106.98 & 99.59 & 107.07 & 101.87 & 95.53 & 110.31 \\
\hline SD & 19.94 & 22.19 & 21.03 & 21.27 & 22.35 & 17.72 \\
\hline Test & $\mathrm{T}=1.95, \mathrm{p}=0.053$ & $\mathrm{~T}=0.87, \mathrm{p}=0.39$ & $\mathrm{~T}=-4.18, \mathrm{p}=0.000$ & & & \\
\hline \multicolumn{7}{|l|}{ Word processing } \\
\hline Mean & 181.25 & 167.43 & 182.75 & 171.86 & 166.73 & 179.88 \\
\hline SD & 25.71 & 20.11 & 21.98 & 23.44 & 24.78 & 20.14 \\
\hline Test & $\mathrm{T}=3.35, \mathrm{p}=0.001$ & & $\mathrm{~T}=1.1 .75 \mathrm{p}=0.08$ & & $\mathrm{~T}=-3.26, \mathrm{p}=0.0$ & \\
\hline
\end{tabular}

\section{DISCUSSION, CONCLUSION AND RECOMMENDATIONS}

ICT has become a central concept in Malaysian educational system. Thus, large sum of money are allocated to provide new infrastructure and to equip schools with newest software and hardware. The availability of these facilities will facilitate the transformation of the nations' educational system. A sum of RM284 million was allocated for the Smart School program and RM1.51 billion was allocated for the computerization of schools. Initially, the SMART School project started with only 90 schools and by 2010 it is estimated that all 10,000 schools in Malaysia will be smart schools. Some 4,500 schools are already equipped with computer laboratories, 99,000 computer units and 4,600 servers. It shows that the Government of Malaysia is determined to develop human capital related to ICT or computer technology. The substantial investment in computer or information technology in schools will be largely wasted if teachers are not prepared to effectively integrate computer technology in teaching.

Based on the present study, it is very likely that the investment by the government will produce successful results. Most of the trainee teachers who were involved in the study felt prepared to integrate computer technology in teaching. This shows that if opportunities are provided to teachers, they will integrate computer in their teaching. However, a report of a study in showed that only $44 \%$ of the new teachers in America are wellprepared to infuse this technology in teaching [5]. There is an increasing concern regarding the extent to which prospective teachers are being prepared to integrate technology to support teaching and learning activities in the classroom [6].

The findings of the study showed that trainee teachers at UPM had the confidence to integrate computer technology in teaching. For example, the study showed that trainee teachers at UPM had moderate knowledge in computing. Most pre-service teachers know very little about effective use of technology in education. After reviewing a number of studies they concluded that while a large number of students in teacher education program were taking some coursework in IT, by and large these instructions were not tied to curriculum, methods, field experience or practice teachings. They had a high level of interest in using computer for teaching [7]. The present study shows that student teachers have positive attitudes about the integration of computer in teaching. They also believed that they had high confidence in using some of the software for teaching purpose. Their attitudes about the integration of computers in teaching are related to 
their perceptions of their abilities to use a number of related software in teaching. This shows that the possibility of integrating computer in teaching is also determined by the attitudes of the prospective teachers. This finding indicated that the integration of computer in teaching would be successful provided the facilities for teachers to use are made available to them. The desire to integrate computer technology in teaching is very important because the classrooms of the past are different from the future. Each of the classrooms could be full of machines eager to be used both by teachers and students for knowledge and skills acquisitions. All classrooms will be connected to the rest of the world and information bad or good is easily accessible. Thus, teachers must have the will, the knowledge and skills needed to work in the future classrooms.

It will be of immense value if computer technology is widely integrated in our educational system. Computer technology has a tremendous effect on efficiency and productivity of education. It is therefore that the education community has urged for the integration of computer technology in the education. Malaysia, for one, will not be facing much of the problem because the study has shown that our trainee teachers have the ability to do just that. This is probably true because our trainee teachers are trained to integrate computer technology in teaching. For the integration to be successful educators must learn through the preservice and in-service training activities, about what computer is, what it can do and how the technology can be used in lesson delivery. In the same vein, teachers need training not only in computer literacy but also in the application of various kinds of educational software in teaching and learning. Furthermore, they need to learn how to integrate ICT into their classroom activities and school structure. Training, which is a big challenge to the teacher training institutions enables teachers to effectively use new learning tools in teaching [8]

The results of the study suggest that integration of technology in teaching is not an easy task and requires high commitment. Trainee teachers will be able to develop competencies only when teacher educators infuse technology throughout the teacher education curriculum. Teacher education program should provide rich learning experiences for pre-service teachers across curriculum and offer them with approaches to reflect on their experiences. It is only through the change in classroom and school practices that the positive benefits of technology to learning will be realized [9]. Teachers themselves must realize the benefits of using computers in teaching. They must have positive attitude towards the use of computers in teaching. Teachers must have certain level of knowledge and skills to be able to use computers in teaching. The infrastructure, of course must be provided to ensure that teachers take advantage of the new teaching tools to the fullest.

\section{REFERENCES}

1. Downes, T., R. Perry and C. Sherwood, 1995. IT in education and teacher education in Australia. J. Comput. Assisted Learning, April, 23-24.

2. UNESCO Asia-Pacific Regional Bureau for Education, 2002. ICT for Education in Asia-Pacific Bangkok, Thailand. http://www.unesco.org/bangkok/ education /ict/teacher_dev/examples7.htm

3. Miller, L.E. and K.L. Smith, 1983. Handling nonresponse issues. J. Extension, 21 (5): 45-50.

4. National Center for Educational Statistics, 1999. Teacher Quality: A Report on the preparation and qualification of public school teachers. US Deaprtment of Education, Washington, DC.

5. Duhaney, D.C., 2001. Teacher education: preparing teachers to integrate technology. Int. J. Instructional Media, 2001, 28 (1): 23-30.

6. Willis, J.W. and H.D. Mehlinger, 1996. Information technology and teacher education. In: Sikula, J., T.J. Buttery and E. guyton (Eds.). Handbook of research on teacher education 2nd Edn. New York: Simon and Schuster Macmillan, pp: 978-1029.

7. Ololube, N.P., 2006. Teachers Instructional Material Utilization Competencies in Secondary Schools in Sub-Saharan Africa: Professional and non-professional teachers' perspective. In Conference Proceedings of the 6th International Educational Technology Conference EMU, 19-21 April 2006 North Cyprus.

8. UNESCO, 2002. Information and communication technologies in teacher education: A Planning Guide. Paris. UNESCO.

9. Muller, L., 2001. Beyond infusion: Pre-service students understandings about educational technologies for teaching and learning. J. Technol. Teacher Edu., 9 (3): 447-466. 